\title{
SIXTH|SYMPOSIUM ON MICRODOSIMETRY
}

Brussels, Belgium, May 22-26, 1978

Commission of the European Communities Directorate-General for Research, Science and Education Biology, Radiation Protection and Medical Research

Edited by

J. Booz and H. G. Ebert

Volume II

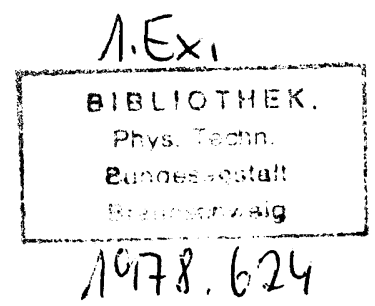

Harwood Academic Publishers Ltd.

for the Commission of the European Communities 
OPENING SESSION

G. SCHUSTER

L.E.FEINENDEGEN

SESSION 1

J.R.K. SAVAGE

G.W. BARENDSEN

SESSION 2

V.P. BOND

D.E. CHARLTON

J. $B O O Z$

J. FIDORRA

Th. SMIT

L.E. FEINENDEGEN

G. TISLJAR-LENTULIS

P. HENNEBERG

Th. MIELKE

L.E. FEINENDEGEN

\section{SESSION 3}

D. FRANKENBERG

M. FRANKENBERG-SCHWAGER

W. GRUNDLER

E.H. KRÜGER

H.G. PARETZKE

W. POHLIT

G. RIMPL

B. FERTIL

P. DESCHAVANNE

B. LACHET

E.P. MALAISE

\section{SESSION 4}

\section{J.L. MAGEE}

A. CHATTERJEE

M. TERRISSOL

J.P. PATAU

T. EUDALDO
Chairman : W.K. SINCLAIR

Address of Welcome

Biological damage from radioactive nuclei incorporated into DNA of cells; implications for radiation biology and radiation protection (invited paper)

Chairman : A. WAMBERSIE

Some thoughts on the nature of chromosomal aberrations and their use as a quantitative end-point for radiobiological studies (invited paper)

RBE-LET relations for induction of reproductive death and chromosome aberrations in mammalian cells

Chairman: J.A. DENNIS

RBE of ${ }^{3} \mathrm{H}$ beta rays and other LOW-LET radiations at Low doses and/or dose rates (invited paper)

Microdosimetry of radioactive nuclei incorporated into the DNA of mammalian cells

DNA strand breaks induced by ${ }^{125}$ I in cultured human kidney cells and their repair

\section{Chairman : N. PARMENTIER}

Radiation studies at the physical, molecular, cellular and macrocolony level

Survival curves of neoplastic and non transformed human cell lines : statistical analysis using different models

Chairman : S. WAGNER

Theory of electron tracks with explicit consideration of track-end effects

Application à la microdosimétrie et à la radiobiologie de la simulation du transport des électrons de basse énergie dans l'eau à l'état liquide 
R.N. HAMM

H.A. WRIGHT

J.E. TURNER

R.H. RITCHIE

\section{SESSION 5}

T. BUDD

M. MARSHALL

C.S. KWOK

M. MARSHALL

B.J. FORSBERG

$T . E$. BURLIN

R. BLOHM

D. HARDER

\section{SESSION 6}

M.N. VARMA

J.W. BAUM

P. KLIAUGA

W.E. WILSON

L.H. TOBUREN

H.G. PARETZKE

L.A. BRABY

W. C. ROESCH

B. FORSBERG

M. JENSEN

L. LINDBORG

G. SAMUELSON
Spatial correlation of energy deposition events

in irradiated liquid water

Chairman : R.V. RECHENMANN

Low pressure cloud chamber studies -

I - Methods of analysis of ionisation distributions

Low pressure cloud chamber studies -

II - The determination of a high resolution tissueequivalent gas for the study of $\alpha$-particle tracks

Relations of secondary electron emission to

microdosimetry and applications to two-target theory

Physical interactions of low-energy electrons in single and twin targets

Chairman : T.E. BURLIN

Microdosimetric results obtained by proportional counter and ionization chamber methods : a comparison

Calculation of energy deposition spectra in small gaseous sites and its applicability to condensed phase

Direct measurements of $f(z)$ for fast electrons

Determinations of the dose mean of specific energy for conventional $x$-rays by variance-measurements

Chairman : M. TERRISSOL

POSTER SESSION I: Particle track structure and slowing down
A. CHAMBAUDET
Diamètre des traces révélées dans quelques
Ph. ROMARY
détecteurs polymériques et parcours "efficace" des
H. ROULET rayons $\delta$

A. CHATTERJEE

J.L. MAGEE

D. COMBECHER

J. KOLLERBAUR

G. LEUTHOLD

H.G. PARETZKE

G. BURGER

8. GROSSWENDT

E. WAIBEL
Relationship of the track structure of heavy particles to the physical distribution and chemical effects of radicals

Energy spectra of degraded electrons in water vapour and in carbon

Determination of backscattering coefficients for Low energy electrons in different gases 
G.S. HURST

S.D. KRAMER

C.E. BEMIS, Jr.

J.P. YOUNG
A. JANSSENS
G. EGGERMONT
R. JACOBS

R.H. RITCHIE

R.N. HAMM

J.E. TURNER

H.A. WRIGHT

M. SCHNEIDER

J. BÖHM

$K$. HOHL FELD

H. REICH

B. SENGER

E. WITTENDORP

R.V. RECHENMANN

J.E. TURNER

R.N. HAMM

H.A. WRIGHT

R.H. RITCHIE

R. KATZ

E. WITTENDORP

B. SENGER

J.B. SANDERS

R.V. RECHENMANN

R. KATZ

SESSION 8

A.M. KELLERER

R. KATZ

SESSION 9

Detection of single atoms in particle tracks

Experimental study of the cavity theory, using a high pressure ionization chamber

331

The interaction of swift electrons with liquid water

Eine Apparatur zur Messung des Verlaufs der Ionendosis an Grenzschichten

$\delta$-ray production along medium energy $\alpha$ particles crossing tissue-like media

Calculated electron slowing-down spectra for liquid water irradiated by $X$ and gamma rays - Implications for photon RBE

Heavy secondaries ejected by primary medium energy $\alpha$ particles crossing dense tissue-like media

Report on poster Session I

Chairman : E. HALL

Radiation carcinogenesis at low doses (invited paper)

High LET constraints on LOW LET survival

Chairman : R. GRILLMAIER

POSTER SESSION II: Application of microdosimetry to radiation therapy

H.I. AMOLS

J.F. DICELLO

M. ZAIDER

L.S. AUGUST

R.B. THEUS

P. SHAPIRO

G. BURGER

E. MAIER

A. MORHART
The RBE at various positions in and near a large negative pion beam

Gamma measurements with a non-hydrogenous Rossi counter in a mixed field

Radiation quality and its relevancy in neutron radiotherapy 


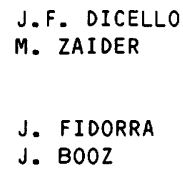

\section{A.G. PERRIS}

D.R. PERRY

F.A. SMITH

G. PFISTER

G. HEHN

J. ZOETELIEF

B. HOGEWEG

J.J. BROERSE

J.J. BROERSE
P. STILLER

Investigation of the microdosimetric characteristics of broad, therapeutic beams of negative pions at LAMPF

The local distribution of radiation quality of a collimated fast neutron beam from $15 \mathrm{MeV}$ deuterons on Beryllium

Prediction of biological effect of pion irradiation using the star distribution to determine the high LET dose

R.b.e. for cell survival at different positions in collimated neutron beams in relation to differences in lineal energy spectra

Neutron absorbed dose measurements in phantom from 252 cf source

Spectres de dépôts d'énergie pour les rayonnements de faible TLE - discrimination neutron gamma dans un champ mixte $n-\gamma$

The calculated mean energy deposition pattern in an ion chamber for neutrons

Experimental microdosimetry at high-LET radiation therapy beams

Calcul des caractéristiques qualitatives (TEL, F.Q., équivalent de dose) d'un faisceau de photons de freinage à usage médical, par simulation de sa création et de son transport

LET in dose distributions, from spectral measurements of charged particles emitted at the capture of negative pions in biologically significant materials

Recoil spectra in neutron irradiated tissues and TE-materials

Radiation quality and absorbed dose at different positions in the primary beam and around the shielding of a neutron generator

Report on poster Session II

\section{SESSION 10 Chairman : A. ALLISY}

(jointly organized by ICRU and EURATOM)

M.J. BERGER Planned compilation of stopping power and range data

H.H. ANDERSEN

Higher-order $z_{1}$ corrections to the Bethe stoppingpower formula

J.A. DENNIS

The dependence of stopping-power on physical and

D. POWERS 
M. INOKUT I

J.E. TURNER
Mean excitation energies for stopping-power as

derived from oscillator-strength distributions

SESSION 11

Chairman: M.J. BERGER

POSTER SESSION III: Stopping power and related subjects

J. CASANOVAS

R. GROB

G. BRUNET

R. SABATTIER

J.P. GUELFUCCI

D. BLANC

J.J. COYNE

L.J. GOODMAN

P. GOUARD

M. CHEMTOB

V.D. NGUYEN

N. PARMENTIER

A.K.M.M. HAQUE

M.J. GEARY

R.B.J. PALMER

A. AKHAVAN-REZAYAT

H.G. PARETZKE

M.J. BERGER

B.G.R. SMITH

J. $\mathrm{BOOZ}$

D.I. THWAITES

D.E. WATT

T.K. YEUNG

D.E. WATT

D.E. WATT

\section{SESSION 12}

D.T. GOODHEAD

J. THACKER

R. $\operatorname{COX}$

P.D. HOLT

D. CHMELEVSKY

A.M. KELLERER

H.H. ROSSI
Détermination du potentiel d'ionisation de certains hydrocarbures en phase liquide

$\bar{W}_{n}$, computed from recent nuclear data and $\bar{W}$ méasurements

Une approche possible de l'étude du ralentissement

des particules chargées lourdes

The stopping power and straggling for alpha particles in liquids

Range-energy relations and stopping power of water, water vapour and $t$ issue equivalent liquid for a particles over the energy range 0.5 to $8 \mathrm{MeV}$

Stopping power and energy degradation for electrons in water vapor

Experimential results on $W$-values and transmission of Low energy electrons in gases

Phase effects in stopping power for low-energy heavy charged particles

Multiple scattering corrections to measurements of stopping power for slow ions

Report on poster Session III

Chairman : W. POHLIT

The conflict between the biological effects of ultrasoft $X$-rays and microdosimetric measurements and application

Micro-dosimetry and nano-dosimetry

Concepts and quantities relevant to the evaluation of charged particle tracks 
R.P. VIRSIK

D. HARDER

C.R. GEARD

A. WAMBERSIE

J. VAN DAM

G. LAUBLIN

Chromosome aberrations in human lymphocytes

induced by photon and electron radiations, and the sublesion interaction model

Microdosimetry and chromosomal aberrations for monoenergetic neutrons

RBE as a function of depth in a $650 \mathrm{MeV} \mathrm{He}{ }^{++}$

beam determined for growth delay in vicia faba and

for induction of chromosome aberrations in allium cepa

\section{SESSION 14}

E.M. FIELDEN

O. SAPORA

P.S. LOVEROCK

\section{S. APELGOT}

J.P. ADLOFF

H.G. PARETZKE

H.H. ROSSI

R. BIRD

R.D. COLVETT

A.M. KELLERER

N. ROHRIG

Y-M.P. LAM
Chairman : G.E. ADAMS

The relation between survival and the initial yield of DNA strand breaks for $E$ coli $B / r$

905

Transmutation effects of ${ }^{32} \mathrm{P}$ and ${ }^{33} \mathrm{P}$ incorporated in DNA

On limitations of classical microdosimetry and advantages of track structure analysis for radiation biology

The molecular ion experiment

\section{SESSION 15}

Chairman : D. HARDER

POSTER SESSION IV: Interpretation of biological data

H.M.A. AL-SHAIBANI

D.E. WATT
M. COPPOLA
M. MARTINELLI
L. TOMMASINO
R. FACIUS
H. BÜCKER
G. REITZZ
M. SCHAFER

R.E. GRILLMAIER

L. BIHY

H.G. MENZEL

H. SCHUHMACHER

R. KATZ

E.C. PENNINGTON

H.P. LEENHOUTS

K.H. CHADWICK

M.J. SIJSMA
Physical processes in the inactivation of enzymes by slow heavy ions

Cell survival and radiation quality

Radial dependence of biological response of spores of Bacillus subtilis around tracks of heavy ions

Chromosome aberration studies and microdosimetry with radiations of varying quality

Radiobiological aspects of supralinear photographic emulsions

The influence of radiation stimulated repair processes on the shape of dose-effect curves 
J.W. PURDIE

E.R. INHABER

N.V. KLASSEN

R.A. ROTH

R. KATZ

M. SCHÄFER

H. BÜCKER

R. FACIUS

G. HORNECK

G. REITZ

G. KRAFT

F. SCHÖPFER

J. KIEFER

E. SCHNEIDER

G. KRAFT

A. TALLENTIRE

D.J.W. BARBER

K.J. WEBER

J. KIEFER

J. KIEFER

SESSION 16

H.H. ROSSI

J.A. DENNIS

\section{SESSION 17}

C.L. GREENSTOCK

R.H. WIEBE

K.H. CHADWICK

H.P. LEENHOUTS
Increased sensitivity of anoxic mammalian cells irradiated with single pulses at very high dose rates

1023

Heavy ion beam model for radiobiology

1033

High LET-irradiation of Bacillus subtilis spores

The inactivation of cells by accelerated heavy ions of very high LET

1051

The interrelationship between pulse length and dose-rate within the pulse in the enhancement of anoxic damage in wet Bacillus megaterium spores irradiated with pulses of electrons

1061

Intracellular measurement of the inactivation of ribosomal RNA genes in diploid yeast cells after exposure to $60 \mathrm{Co}-\gamma$-rays, $85 \mathrm{kV} \mathrm{X}$-rays and 241-Americium- $\alpha$-particles

1071

Report on poster Session IV 1081

Chairman : A.M. KELLERER

Radiation quality and quality factor (invited paper)

1087

Dose limits and quality factors: the Devil's view

Chairman : J.J. BROERSE

Chemical mechanisms of the interaction between radiation and chemical carcinogens

The implications for radiological protection of the synergistic interaction between radiation and other DNA damaging agents

Chairman: K.H. CHADWICK

The molecular and cellular basis of the oxygen effect
J. KIEFER
H. KOCH
K. KOESTER
G. MOCK
E. SCHNEIDER
K. WEBER 
K.F. BAVERSTOCK W.G. BURNS

R. MAY

\section{SESSION 19}

R.S. CASWELL

J.J. COYNE

P. KLIAUGA

R.D. COLVETT

L.J. GOODMAN

Y.M. LAM

A.K.M.M. HAQUE

S.A. SAQ'AN

\section{SESSION 20}

C. HERSKIND

K.A. JESSEN

W.C. ROESCH

J. $800 z$

\section{APPENDIX 1}

\section{G.E. ADAMS}

J. 8002

J.A. DENNIS

L. LINDBORG

M. TERRISSOL

G. TISLJAR-LENTULIS

APPENDIX 2
The oxygen in the track hypothesis: Microdosimetric implications

Chairman : H. DE CHOUDENS

Energy deposition spectra for neutrons based on recent cross section evaluations

Microdosimetry of $400 \mathrm{MeV} / \mathrm{AMU}{ }^{12} \mathrm{C}$ and $450 \mathrm{MeV} / \mathrm{AMU}$
$4 \mathrm{O}_{\mathrm{Ar}}$ beams

Microdosimetric study with cylindrical walled and wall-less proportional counters

Chairman : J. BOOZ

Measurements in internal microdosimetry with a wall-less proportional counter

Internal microdosimetry

Closing of the symposium

Personal impressions and reviews of discussions

Some discussion comments on the mechanisms of sensitizers

Summary of the discussions concerning radiation mechanisms of external radiations

Impressions of the 6th Microdosimetry Symposium and its relevance to radiological protection

Summary of discussions on evaluation of microdosimetry data

Summary of the discussions concerning electron track structure and microdosimetry

Summary of the discussions concerning incorporated radioisotopes

List of participants 
THE MOLECULAR ION EXPERIMENT**

H.H. Rossi, R. Bird, R.D. Colvett, A.M. Kellerer, N. Rohrig* and Y-M.P. Lam

Radiological Research Laboratory, Columbia University

630 West 168th Street, New York, New York 10032

and

*Medical Department, Brookhaven National Laboratory, Upton, New York

\section{Abstract}

In early simplifications of the Theory of Dual Radiation Action it was assumed that ionizing radiations produce lesions which arise from the combination of pairs of sublesions that are produced in "sites", i.e. limited regions in the cell nucleus in which this combination can take place. In a more realistic treatment, the probability of combination depends on the separations at which the sublesions can be produced and the probability that combination occurs if such initial separations intervene. The molecular ion experiment is designed to determine this dependence. Pairs of ions with varying mean spacing are generated by the break-up of molecular ions and subsequent divergence by multiple coulomb scattering in a foil. The emergent ions traverse mamalian cells attached to the exit side of the foil.

The principles of the experimental techniques are discussed and some initial results are presented.

**This investigation was supported by Grant Numbers CA 15307 and 12536, awarded by the National Cancer Institute, DHEW, and by Contract EP-78S-02-4733 from the U.S. Department of Energy. 


\section{Background and objective:}

The concepts of microdosimetry were developed because the cells of higher organisms usually respond to ionizing radiation in a non-linear manner, in that different distributions of absorbed energy result in different frequencies of effects. The identification of pertinent microdosimetric quantities must however be governed by the nature of the dependence of effect frequency on energy concentration and by the magnitude of the domains in which energy concentration is significant.

The Theory of Dual Radiation Action provides answers to both of these questions by its postulate that radiation injury is due to lesions which in turn result from the pairing of sublesions that have been produced at separations that are typically $1 \mu \mathrm{m}$. In an early formulation (1) it was stated that $\varepsilon(z)$, the yield of lesions, is proportional to the square of the specific energy, $z$, or

$$
\varepsilon(z)=K z^{2}
$$

where $K$ is a constant and $z$ is the value of the specific energy in sites (i.e. subnuclear volumes) having a diameter of about $1 \mu \mathrm{m}$.

Eq. (1) is equivalent to

$$
\varepsilon(D)=K\left(\zeta D+D^{2}\right)
$$

where $D$ is the absorbed dose and $\zeta$ the dose mean of the specific energy produced by individual events in the sites.

It was recognized that this formulation can only be an approximation for a number of reasons. These include the necessity of corrections for saturation and for variation of $K$ with radiation quality. An additional 
simplification consists in the assumed existence of sites in which there is constant probability of interaction between sublesions. There is no cytological evidence for the existence of such volumes and it seems much more likely that sublesions are produced throughout the nucleus and that they combine with a probability that depends on their separation. The initial separation of combining sublesions is then on the average about equal to the radius of the hypothetical sites.

In a recent generalization (2) of the Theory of Dual Radiation Action the site concept has been eliminated and the relation given in Eq. 2 has been replaced by

$$
\varepsilon(D)=K\left(\xi D+D^{2}\right)
$$

$\xi$ is proportional to the integrated product of three functions: $s(x) d x$, the expected volume of matrix at a distance $x$ to $x+d x$ from a sublesion. The matrix is that portion of nuclear material in which sublesions can be produced.

$g(x)$, the average probability that a pair of sublesions separated by $x$ combines to form a lesion.

and $t(x) d x$, the mean energy deposited by the same event at a distance $x$ to $x+d x$ from an energy deposit.

The normalized product

$$
\Phi(x)=g(x) s(x) / \int_{0}^{\infty} g(x) s(x) d x
$$

may be termed the availability of adjacent loci. If sublesions are produced randomiy in the matrix, i.e. if energy is uniformly imparted to the medium, $\Phi(x) d x$ is the fraction of lesions resulting from two sublesions that were produced at a separation $x$ to $x+d x$. The site radius applicable 
to the site model should be comparable to $\int_{0}^{\infty} x \Phi(x) d x$.

Since $\Phi(x)$ characterizes the dependence of sublesion combination on separation, it is a basic function of radiobiology. The determination of its values for inactivation of tissue culture cells is the objective of the molecular ion experiment.

\section{Basic plan of experiment:}

The most direct determination of $\Phi(x)$ would be one in which radiation is administered in pairs of energy deposits of varying separation. However this does not seem feasible because of the inherent track pattern of energy deposition.

A less direct but achievable method consists in the employment of short tracks of varying length. Monoenergetic $x$ rays having energies of the order of one keV or monoenergetic neutrons of somewhat higher energy could be employed to determine the value of the integral given above over various finite intervals. Other studies with such radiations have in fact been carried out $(3,4,5)$. There is however a major difficulty in that, as already mentioned, $K$ which depends on the effectiveness with which sublesions are produced is very likely to depend on LET. The nature of this dependence is largely unknown but it may be expected to be especially pronounced near the ends of tracks.

This difficulty can be avoided if the irradiation is by pairs of parallel tracks with variable spacing and this is the modality that has been adopted. Because of problems of scattering and the minute separations required, it was deemed impractical to utilize collimated particles, and uncollimated molecular ions are employed instead. Although protons as well as deuterons are used and the molecules can be triatomic as well as diatomic, 
the remainder of this discussion will deal with diatomic deuterium molecules.

The ion source of the RARAF Van-de-Graaff accelerator provides an ample supply of $\mathrm{D}_{2}{ }^{+}$ions which are readily segregated by a magnetic field. When these molecules strike a foil, the electron joining the deuterons is stripped off and the two nuclei proceed independently in tracks that are not strictly rectilinear because of multiple coulomb scattering. It can be shown that for any foil thickness, a, the separation, $s$, of the emerging particles is very nearly distributed as

$$
f(s)=s / B^{2} \cdot \exp \left(-s^{2} / \beta^{2}\right)
$$

where $B$ is a constant that is inversely proportional to particle energy, proportional to the square root of $a$, and dependent on the material of the foil. Scattering of single particles was studied to determine $\beta$ and to obtain slight corrections to Eq. 5 .

In this irradiation modality there is no fixed separation of tracks but a distribution having a width that depends on $B$. However this poses no substantial problem since $t(x)$ can be calculated for either condition following approaches previously outlined (6).

The basic experiment consists in irradiating cells attached to thin sheets of mylar with deuteron molecules that are incident on the opposite surface. The survival of cells is compared with that obtained with equal numbers of single deuterons of the same energy. This condition is attained by the simple expedient of introducing a very thin scattering foil into the beam pipe at some distance upstream from the cells. There is negligible probability that following break-up by this foil, both deuterons pass through the same cell. The ratio of survivals for uncorrelated and correlated deuterons is studied as a function of foil thickness, allowance being made for 

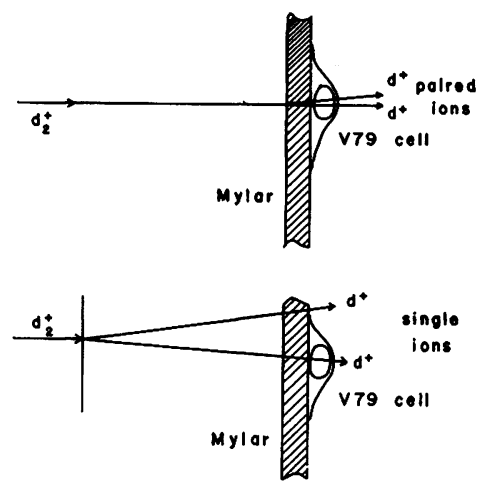

1. Schematic representation of irradiation by molecular ions. The molecular ions dissociate either in a foil contiguous to the cells or they are dissociated at some distance upstream from the cells. The lower sketch is not to scale since the thickness of the cells and the supporting mylar are of the order of a micrometer while the separation of the breakup foil from the foil-cell combination is on the order of meters.

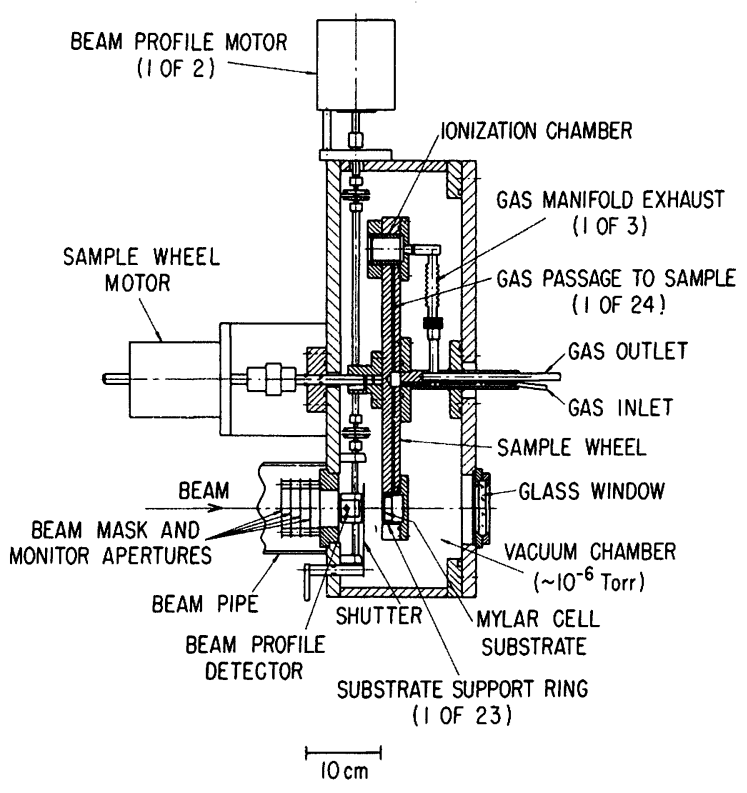

2. A schematic cross-sectional drawing of the irradiation facility of the molecular ion experiment. The major components are identified. 
an additional mean separation due to scattering in the cells which are about as thick as the thinnest foil employed $(\sim 4 \mu \mathrm{m})$. The mean separation at median cell depth has, in experiments carried out thus far, ranged from about 90 to about $250 \mathrm{~nm}$.

In these experiments V79 hamster cells are utilized and they are synchronized because it was anticipated that $\Phi(x)$ might depend on cell age.

\section{Technical features:}

A series of papers will describe the various details of the molecular ion research. Although the principle of the experiments is relatively simple, substantial practical difficulties had to be overcome. Here only a few salient features will be mentioned.

The need to irradiate the cells in dishes having a diameter of several $\mathrm{cm}$ results in a mechanical problem since the thin foils are liable to rupture when subjected to a pressure differential of one atmosphere between the vacuum chamber and the cell environment. It has thus been found necessary to expose the cells when they are in gas at 1/10 atmosphere pressure. This in turn requires rapid evacuation and careful control of humidity. However even under the optimum conditions available, it is not possible to avoid the trauma that is caused by the irradiation environment together with that introduced by synchronization with hydroxyurea. In order to reduce the limits of error, a considerable number of dishes are irradiated to equal numbers of associated or random particles with other dishes serving as controls. (Fig. 1)

The dishes are placed into a large wheel that rotates at a rate that is proportional to the dose rate as measured by a current monitor. The beam is delimited by a slit and the wheel rotates in steps of 5 min of arc 


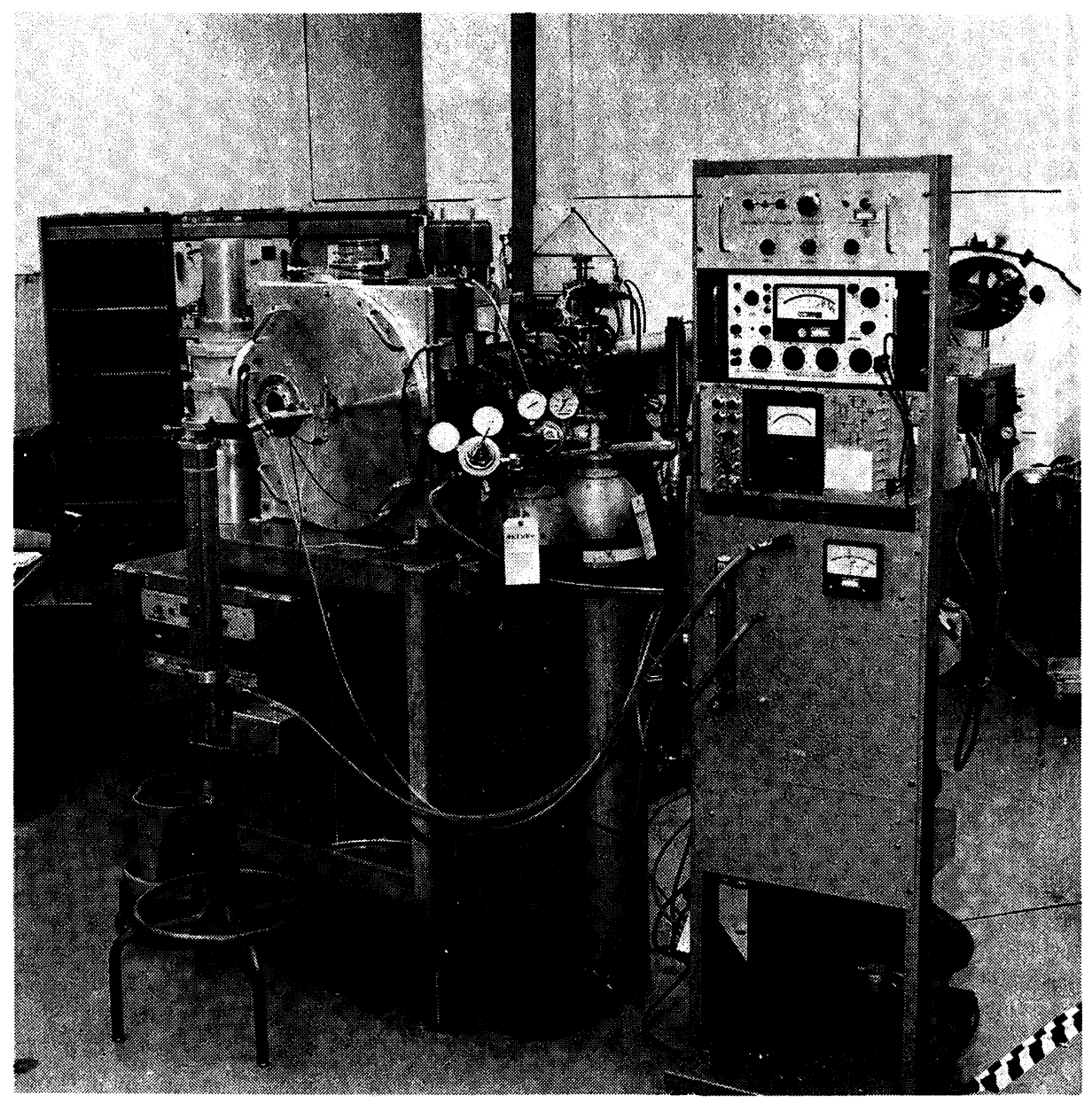

3. Photograph of the irradiation facility for the molecular ion experiment. Most of the apparatus surrounding the irradiation chamber (large aluminum box) serves to control the cell environment. 
when ever a predetermined fluence has passed through the slit. This ensures uniformity of irradiation. Two of the positions on the wheel are occupied by dosimeters. All of the operations including wheel motion, insertion of the break-up foil, dosimetry, etc. are controlled by an on-line computer. Fig. 2 is a schematic drawing of the irradiation chamber and Fig. 3 is a photograph showing some of the peripheral equipment as well.

The assay of cell survival is carried out by standard techniques.

\section{Initial results:}

Although a considerable number of irradiations have been carried out, the results obtained to date are for only 3 foil thicknesses. They are given primarily to show that the expected effect does indeed exist. As also anticipated, it is more pronounced in late $S$ than at the $G_{1} / S$ interface presumably because of differences in the aggregation of DNA.

Fig. 4 shows the survival ratio as a function of absorbed dose for cells in late $S$ for three different foil thicknesses and Fig. 5 shows the corresponding data for $G_{1} / S$. The survival ratio is defined for equal doses as the ratio of survival with random particles and that with associated particles. It is evident that in general, with increasing correlation (i.e. with decreasing foil thickness), the effectiveness of deuterons increases, particularly in late $S$.

No definitive attempt has been made to determine $\Phi(x)$ although the methods for such an analysis are at hand, including adequate formulation of $t(x)$. However, it would appear on the basis of initial considerations that $\Phi(x)$ may turn out to have a complex shape in which the function decreases rather rapidily at low $x$ but much more slowly at large $x$. Verification of this impression must await the results of further experiments. 


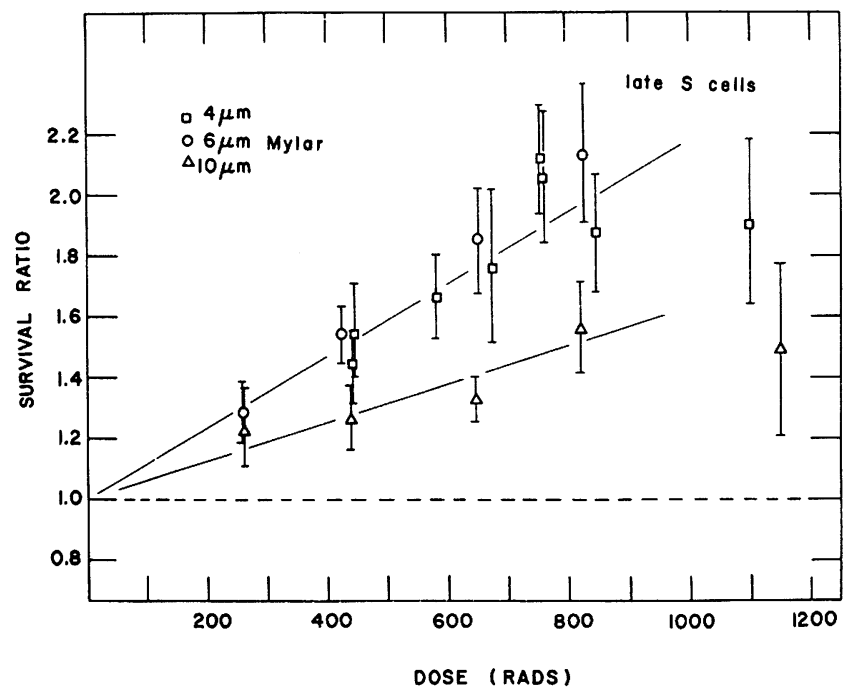

4. Preliminary data on the relation between the survival ratio (ratio of survivals with uncorrelated and correlated ions) as a function of absorbed dose. The data are for cells in late $S$ phase attached to foil of the indicated thicknesses.

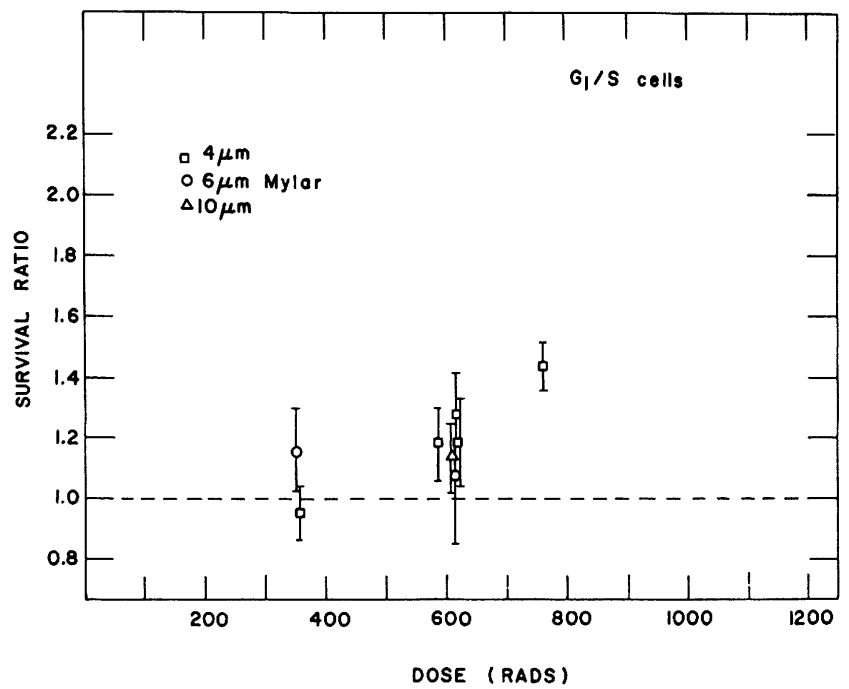

5. Preliminary data on the relation between the survival ratio (ratio of survivals with uncurrelated and correlated ions) as a function of absorbed dose. The data are for cells in $G_{1} / S$ interface attached to foil of the indicated thicknesses. 


\section{Acknowledgements:}

William Gross, Leon Goodman, and E.J. Hall made major technical contributions to this work and we are grateful for their help.

\section{REFERENCES}

1. Kellerer, A.M. and Rossi, H.H. "The theory of dual radiation action." Current Topics in Radiation Res. Quart. $\underline{8}, 85-158$ (1972).

2. Kellerer, A.M. and Rossi, H.H. "A generalized formulation of dual radiation action." Radiat. Res. (in press).

3. Neary, G.J., Preston, R.Y., and Savage, J.R.K. "Chromosome aberrations and the theory of RBE. III. Evidence from experiments with soft X-rays, and a consideration of the effects of hard X-rays." Int. J. Radiat. Biol. 12, 317-345 (1967).

4. Cox, R., Thacker, J., and Goodhead, D.T. "Inactivation and mutation of cultured mammalian cells by aluminum characteristic ultrasoft $X$-rays. II. Dose-responses of Chinese hamster and human diploid cells to aluminum $X$-rays and radiations of different LET." Int. J. Radiat. Biol. 31, 561-576 (1977).

5. Geard, C.R. and Rossi, H.H. "Microdosimetry and chromosomal aberrations for monoenergetic neutrons." (presented at this symposium).

6. Kellerer, A.M. and Chmelevsky, D. "Concepts of microdosimetry. III. Mean values of the microdosimetric distributions." Rad. and Environm. Biophys. 12, 321-335 (1975). 